\title{
Toward a New Salvage Regime for Environment: Reformation of the International Convention on Salvage 1989 and Thailand's Implementation
}

\section{Patthara Limsira*}

The Salvage Convention 1989 establishes the main international legal framework dealing with salvage operations and environmental protection. It is the result of many years of drafting and diplomatic efforts where the treaty was negotiated and concluded. It is undeniable that the Salvage Convention 1989 has encouraged private sector and public authorities to establish and maintain the resources needed to contain ecological damage. This was an important accomplishment. Providing adequate incentives for rapid salvage operation adds to the traditional rewards. Nevertheless, the problems of updating the provisions of the Salvage Convention 1989 need to be addressed and the path ahead is still long and winding. In particular, the importance of environmental considerations is increasingly significant. As a result, modern salvage operations must also take into account measures to prevent damage to the environment. Today's international community is searching for a new salvage regime and law. This paper examines the possibility of building the new salvage regime and its implementation in Thailand.

\section{Keywords}

Salvage Convention 1989, Thailand, Lloyd's Open Form, IMO, Marine Salvage Act

\section{Introduction}

Maritime salvage is the process of recovering a ship, along with its cargo, which is in distress due to an emergency or localized danger that puts the vessel at risk

* Assistant Professor at Faculty of Law, Ramkhamhaeng University, Thailand. LL.B.(Cum Laude)/LL.M. (Chula.) The author may be contacted at: patthara@ru.ac.th.

All the websites cited in this article were last visited on May 8, 2020. 
of complete loss. ${ }^{1}$ Over the long history of the maritime law regime, salvage is considered an ancient and uniform situation. It was included in the Rhodian sea law, ${ }^{2}$ which dates back to about 3,000 years ago. ${ }^{3}$ At that time, volunteer salvors ${ }^{4}$ in Greece and other Mediterranean areas earned rewards for their services. The fundamental concept of salvage was also adopted in Justinian's Digest under the Roman legal system, ${ }^{5}$ holding that the salvors should be encouraged by reasonable rewards in salvage operations, ${ }^{6}$ to save cargoes from misappropriation or burglary. ${ }^{7}$

Since the eighteenth century, a policy of "no cure-no pay" has been an imperative principle in marine salvage. The salvor shall be paid only for successful salvage. ${ }^{8}$ The ceiling of the reward shall not exceed the value of the property recovered. ${ }^{9}$ Nowadays, the importance of environmental considerations is increasingly significant, and the cost of undoing harm to the coastal environment due to spillage of oil or other contaminants is much higher than the cost of measures to prevent or mitigate the harm before it occurs. ${ }^{10}$ As a result, modern salvage operations cannot be focused only on the ship or the cargo, but must also take into account measures to prevent damage to the environment. Due to the highly competitive and highly profitable nature of today's salvage market, most salvage operations are now carried out by specialist salvage firms ${ }^{11}$ with trained or professional personnel and dedicated equipment.

1 G. Brice, Brice on Maritime Law of Salvage 1 (5th ed., 2011). See also F. Rose, Kennedy \& Rose: Law of Salvage 1 (9th ed. 2017). Under customary international law, the principles or ingredients of salvage are peril, voluntariness, success, place of rendering the services and the type of property salved. See W. Tetley, Maritime Liens and Claims 330-338 (2d ed., 1998). The existence of peril is the key to determine between salvage and towing; V. Quinn, Hard Aground: A Primer on the Salvage of Recreational Vessels, 19 U.S.F. MAR. L. J. 332 (2007).

2 W. Ashburner, The Rhodian Sea Law 288 (1909). See also R. D. Benedict, The Historical Position of the Rhodian Law, 18 YaLe L. J. 223-242 (1909).

3 L. Paine, The Sea and Civilization: A Maritime History of the World 57-78 (2013).

4 Voluntariness is an essential element of salvage. See W. Tetrey, International Maritime and Admiralty LaW 330 (2002).

5 Brice, supra note 1, at 5. See also R. P. Grime, ShipPIng Law 276 (1978).

6 P. Mukherjee, Essentials of General Average: A Synoptic Overview of an Ancient Maritime Law, 6 WMU J. MAR. AfF. 21-36 (2007).

7 T. Schoenbauum, Admiralty and Maritime Law 783 (2004).

8 For the legal analysis of "no cure-no pay" principle, see A. Mandaraka-Sheppard, Modern Maritime Law (vol. 2): Managing Risks and Liabilities 482 (3d ed., 2014); R. Shaw \& M. Tsimplis, The Liabilities of the Vessel, in Maritime LAW 250-1 (Y. Baatz ed., 2011).

9 S. Baughen, Shipping Law 274 (5th ed. 2012).

10 M. Mudric, Liability Salvage - Environmental Award: A new Name for an Old Concept, 49 PoredBeno Pomorsko Pravo 471-792 (2010).

11 The International Salvage Union ("ISU") is an association representing the interests of 60 major salvors worldwide, who conduct over $90 \%$ of all salvage activity. Membership of the ISU is restricted to those companies with a record of successful salvage and pollution prevention. Members are required to have the high level of expertise expected of the professional salvor. According to ISU Annual Review 2018, gross revenue for ISU members was USD 409 million and in the last 4 years were USD 409 million (2017), USD 380 million (2016), USD 717 million (2015) and USD 776 


\section{Types of Salvage}

There are two basic types of salvage, namely merit salvage and contract salvage. ${ }^{12}$ Merit salvage, also called pure salvage, is an operation without contract or other preexisting agreement between the owner of the goods and the salvor. The salvage reward shall be based on the merit of the service and the value of the salvaged property, as decided by a court ${ }^{13}$ or an arbitration. ${ }^{14}$ Contract salvage is meanwhile an operation where the salvor and the vessel's owner enter into a contract before commencement of salvage operations. ${ }^{15}$ A unique form of contract, Lloyd's Open Form ("LOF"), drafted in 1892, continues to evolve today. ${ }^{16}$ The LOF is accepted as the standard form for salvage operations and remains the most frequently used salvage contract. ${ }^{17}$ There are also various national forms ${ }^{18}$ to govern any salvage operations in the maritime zones of particular countries or where nationals of the particular countries are involved. Some forms are drafted by international organizations, such as the Baltic and International Maritime Council ("BIMCO") Forms. ${ }^{19}$ Although LOF is still the most profitable salvage contract for salvors as well as the first option discussed in the bargaining process, shipowners prefer salvage contracts that are

million (2014). See ISU, ANNUAL Review 2018, 10 (2017).

12 Which both types still apply the same salvage principle. See C. Hill, Maritime Law 184 (1981).

13 E.g. U.S. Supreme Court on Blackwell case, 77 U.S. (10 Wall.) 1 (1869), set out the list of six factors determining the amount of the reward for a salvage service: 1) The labor expended by the salvors in rendering the salvage service; 2) The promptitude, skill, and energy displayed in rendering the service and saving the property; 3) The value of the property employed by the salvors in rendering the service, and the danger to which such property was exposed;4) The risk incurred by the salvors in securing the property from the impending peril; 5) The value of the property saved; and 6) The degree of danger from which the property was rescued. However, each factor carried unequal weight. See R. Posner, A Theory of Negligence, in Economic Analysis of Tort and Products Liability Law: A Collection of Essays \& CASES 101-4 (J. Wahl ed., 1998).

14 M. Cohen, Travails of the flying Dutchmen: Lloyd's standard form of salvage agreement and the US salvage industry. 6 MARINE POL'y 265-86 (1982).

15 O. Lennox-King, Laying the Mark to Port and Starboard: Salvage under Duress and Economic Duress at Contract Law, 21 AustL. \& N.Z. MAR. L. J. 32-69 (2007).

16 The first LOF has been used in the salvage industry for more than one hundred years before revision. Generally, the LOF provides England with an appropriate forum for litigation and London for arbitration. A major distinction of the LOF is that the parties are admitted that the vessel was in danger. See BAUGHEN, supra note 9, at 274.

17 J. Witte, Jr., The Importance of Lloyd's Open Form Salvage Contract, Marine News 18 (2014).

18 E.g. Beijing Form, French Form, German Form, Japanese Form, Moscow Form, Scandinavian Form, Turkish Form, and the US Form. See C.-S. Chiu, et al., Cost of salvage: A comparative form approach, 25 J. MARINE SCI. \& TeCH. 743-2 (2017); M. Mudrić, Standard Form Salvage Contracts: The scope of the duty to exercise best endeavours, 19 J. INT'L MAR. L. 220-36 (2013).

19 BRICE, supra note 1, at 94-5. See also The Baltic and International Maritime Council, Contracts and Clauses, available at https://www.bimco.org/contracts-and-clauses/bimco-contracts. 
calculated based on daily rates or a lump sum instead of using LOF if it is all possible. $^{20}$

\section{Historical Background of the Salvage Convention 1989}

The dawn of modern salvage operations treaty came when only seven nations controlled over eighty percent of the maritime shipping operation in the world, and almost half of them were registered under the British Empire. ${ }^{21}$ In addition, most of the domestic salvage laws were very similar, since they were all derived from the same principles of Roman Law. ${ }^{22}$ As the result, the Brussels Convention for the Unification of Certain Rules with Respect to Assistance and Salvage at Sea (hereinafter Salvage Convention 1910) ${ }^{23}$ was drafted by the Comité Maritime International ("CMI") in Brussels, in order to crystalize the legal regime of salvage. Without any surprise, the Salvage Convention 1910 was heavily influenced by the English maritime law's principle of "no cure-no pay," 24 which was widely accepted as an international rule of salvage at that time. ${ }^{25}$ This position was also reflected in the contents of the LOF. ${ }^{26}$

The years passed by and the world underwent dramatic changes. Serious problems emerged that affected the financial position of salvors. These included the notion of environmental protection. ${ }^{27}$ The contents of the Salvage Convention 1910 were showing their age and needed to be revised. However, most State parties and international organizations seek to avoid opening Pandora's box of renegotiating the Salvage Convention 1910. Therefore, the solutions offered by the international community addressed only the physical problems of pollution. In this period, several treaties were introduced concerning the matter, in particular the Prevention,

20

21 W. Reynardson, Unification of International Maritime Law. The Work of the Comité Maritime International, in Demetrios Markianos: In Memoriam 317 (1988).

22 W. Hastings, Non-Tidal Salvage in the United Kingdom: Goring, Goring, Gone, 19 J. Mar. L. \& Com. 473 (1988).

23 T.S. No. 576, 37 Stat. 1658. U.K.T.S. 1913, No. 4. Also including Protocol to Amend the Convention for the Unification of Certain Rules of Law Relating to Assistance and Salvage at Sea 1967, U.K.T.S. 1978, No. 22.

24 It was rather based on the Civil Law principle of assistance. See W. Tetley, Savage, in InTERnational EnCYCLOPEDIA OF Comparative Law (Vol. 12): Law of Transport 96-7 (K. Zweigert \& U. Drobnig eds., 1981).

25 BAughen, supra note 9, at 275.

26 The relationship between salvage operation and the Lloyd's Open Form still accepted as the standard. See N. Gaskell, The 1989 Salvage Convention and the Lloyd's Open Form (LOF) Salvage Agreement 1990, 16 Tul. MAr. L. J. 1 (199192).

27 M. Kerr, The International Convention on Salvage Convention 1989: How it Came to be, 39 InT'L \& Comp. L. Q. 532-3 (1990). 
Intervention and Liability Conventions, ${ }^{28}$ the Fund Convention $1971 ;{ }^{29}$ and the MARPOL 73/78. ${ }^{30}$ The elements of those treaties focused solely on compensation for pollution management. None of them dealt directly with the causes of the problems, which were remuneration and environmental protection.

At the same time, developments in the technology of shipbuilding led to everlarger vessels being built to transport hazardous substances across the ocean. This progression led to several notorious incidents of pollution, inter alia, Torrey Canyon ${ }^{31}$ and Amoco Cadiz. ${ }^{32}$ Those disasters led salvors to offer new services to seek rewards in this novel scenario. Salvage operation may not be practicable, but coastal States were seeking help to avoid environmental harms.

Subsequent events included the 1980 amendments of LOF, ${ }^{33}$ the Legal Committee of Inter-Governmental Maritime Consultative Organization to review the liability salvage's principle, ${ }^{34}$ and the Montreal Compromise. ${ }^{35}$ Those progressive events clearly illustrated the need for a new treaty to replace the outdated one.

As a result, sixteen States and observers from nineteen non-governmental international organizations met together in London for a diplomatic conference. They concluded a new international salvage law in April 1989. This was the International Convention on Salvage 1989 (hereinafter Salvage Convention 1989), ${ }^{36}$ relying on the

28 E.g. International Convention for the Prevention of Pollution of the Sea by Oil 1954, as amended in 1962 and 1969; International Convention Relating to Intervention on the High Seas in Cases of Oil Pollution Casualties 1969; and the International Convention on Civil Liability for Oil Pollution Damage 1969.

29 The International Convention on the Establishment of an International Fund for Compensation for Oil Pollution Damage 1971, which was later replaced by the International Convention on the Establishment of an International Fund for Compensation for Oil Pollution Damage 1992, and referred to as FUND92.

30 International Convention for the Prevention of Pollution from Ships, 1973 as modified by the Protocol of 1978.

31 It was the first major pollution disaster that occurred in 1967. A Liberian oil vessel spilled more than a million barrels of oil as a result of its grounding near the southwest of England. The salvage operation was unsuccessful, so that the salvors could not claim rewards. See Barracuda Tanker Corporation and Union Oil Company of California v United Kingdom of Great Britain and Northern Ireland, Republic of France and States of Guernsey (The "Torrey Canyon") [1969] 2 Lloyd's Law Rep 591. See also T. Cooper \& A. Green, The Torrey Canyon Disaster, Everyday Life, and the "Greening” of Britain, 22 Envtl Hist. 101-26 (2017).

32 The notorious impact of Amoco Cadiz disaster in 1984 was a very large crude carrier's steering gear failure. It spilled 223,000 tons of crude oil, spreading across 125 miles off the coast of Brittany. Dispite the efforts of 10,000 French soldiers deployed to clean the polluting beaches, the disaster still destroyed fisheries, oyster and seaweed beds. See the “Amoco Cadiz" [1984] 2 Lloyd's Law Rep 304; L. Rosenthal \& C. Raper, Amoco Cadiz and Limitation of Liability for Oil Spill Pollution: Domestic and International Solutions, 5 VA. J. NAT. Resources L. 259-95 (1985). This disaster took more than a decade to settle the claim. See C. Redgwell, The Greening of Salvage Law, 14 Marine PoL'y 142 (1990).

33 A. Miller, Lloyd's Standard Form of Salvage Agreement - LOF 1980: A Commentary 12 J. MAR. L. \& Com. 243 (19801981).

34 Kerr, supra note 27 , at 537-8.

35 It was a crucial event that led to the concept of special compensation. See id. 538-40.

361953 U.N.T.S. 165. See generally F. Berlingieri \& International Maritime Committee, The Travaux Preéparatoires of the Convention on Salvage Convention 1989 (2003). 
International Maritime Organization ("IMO"), with the assistance of the CMI. The Salvage Convention 1989 entered into force on July 14, 1996 with the ratification of fifteen State parties. ${ }^{37}$

\section{Environment Protection under the Salvage Convention 1989}

The Salvage Convention 1989 provides thirty-four articles divided into five chapters as the new core of the provisions to protect against and minister to environmental damage. Therefore, if the vessel threatens damage to the environment, ${ }^{38}$ the Salvage Convention 1989 encourages salvors and shipowners with appropriate incentives to protect the environment in four measures as follows.

First, the Salvage Convention 1989 imposes on shipowners and salvors reciprocal duties to exercise due care to minimize damage to the environment. ${ }^{39}$ Regardless of contract terms, those reciprocal obligations are binding the owners and salvors. ${ }^{40}$

Second, the determination of the salvage reward shall take into consideration the skill and efforts of the salvors in preventing or minimizing damage to the environment. ${ }^{41}$ The reward shall also consider the factors of the salvor's liability risks, the state of readiness of the salvor's equipment used in the operation, and the specialized nature of that equipment.

Third, the fixed reward ${ }^{42}$ shall be paid by vessel and cargo owners. ${ }^{43}$ The reward may also provide special compensation to salvors who assist a vessel in threatening damage to the environment even if the operation was unsuccessful. ${ }^{44}$ The vessel owner may be responsible for special compensation, ${ }^{45}$ which includes salvor's expenses plus an additional thirty percent of expenses, ${ }^{46}$ and up to double in extraordinary cases. ${ }^{47}$ This special compensation may be paid only to the extent that it

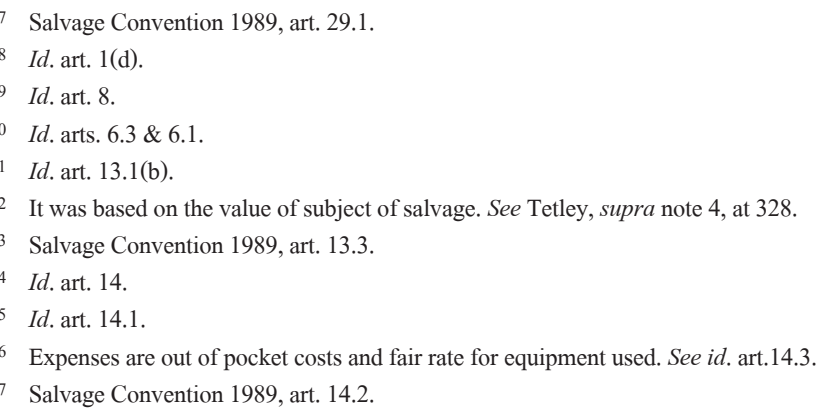


exceeds amounts under the fixed reward. ${ }^{48}$ In situations where the salvor negligently fails to minimize damage to the environment, special compensation may be reduced or eliminated. $^{49}$

Fourth, although the Salvage Convention 1989 does not oblige State parties to support salvage operations, it requires them to take into account the need for cooperation among the private parties and public authorities involved in salvage operations to minimize damage to the environment. ${ }^{50}$ This reflects the importance of cooperation between the State parties, vessel owners, and salvors.

\section{The Development Issues in the Savage Convention 1989}

The marine salvage industry has undergone significant development since the conclusion of the Salvage Convention $1989 .^{51}$ This has drawn attention to the aging provisions of the Convention and demonstrated its shortcomings. ${ }^{52}$ There is the notion that the Salvage Convention 1989 should be comprehensively reformed in order to rebalance the environmental protection paradigm between the interests of the salvage industries and the states ${ }^{53}$ as follows:

It is common practice that governments of coastal States have refused to provide places of refuge where there was a risk of marine pollution to the offshore environment. ${ }^{54}$ Consequently, salvors are left with the option of towing the stricken vessels into the far recesses of the oceans to sink such vessels. This still leads to negative environmental impacts on the area and nearby coastal States. ${ }^{55}$

Id. art. 14.4

Id. art. 14.5 .

$50 \quad I d$. art. 5.1-5.2.

51 National Research Council, Reassessment of the Marine Salvage Posture of the United States 13-22 (1994).

52 O. Adascalitei, The 1989 Salvage Convention and the protection of the environment-should the actual compromise continue?, 8 Juridical Tribune 64-73 (2008). See also G. Beale, Environmental Salvage and the 1989 Salvage Convention: Proposed Amendments to the Convention and Difficulties in Quantifying an Environmental Salvage Award, 16 EnvtL. L. Rev. 248-61 (2004).

53 G. Beale, Environmental Salvage and the 1989 Salvage Convention: Proposed Amendments to the Convention and Difficulties in Quantifying an Environmental Salvage Award, 16 EnvtL. L. Rev. 248-61 (2014). See also M. Mudrić \& I. Vio, CMI Beijing Conference and 1989 Salvage Convention 2-4 IL Dirtto Marittimo 412-25 (2014).

54 Y. Tanaka, Key Elements in International Law Governing Places of Refuge for Ships: Protection of Human Life, State Interests, and Marine Environment, 45 J. Mar. L. \& Com. 158 (2014). See also A. Morrison, Places of Refuge for Ships in Distress: Problems and Methods of Resolution 9-51 \& 177-284 (2012).

55 A. Bishop, The Development of Environmental Salvage and Review of the London Salvage Convention 1989, 37 TUL. 
Based on their interpretation of the term "fair rate" in the Nagasaki Spirit case, the response of the international community and maritime industry was to propose the Special Compensation P\&I Club Clause ("SCOPIC") ${ }^{57}$ on a voluntary basis. The SCOPIC scheme of special compensation as a safety net to ensure a minimum payment has been updated several times addressing problems. In practice, the SCOPIC has been a replacement for Article 14 of the Salvage Convention $1989 .{ }^{58}$

Furthermore, in response to the development of technology for marine archaeology, there is a regime concerning salvage operations that seek to salvage underwater cultural heritage. The salvage of old shipwrecks can be very profitable. ${ }^{59}$ Although a competing treaty like the Convention on the Protection of the Underwater Cultural Heritage was adopted in 2001, ${ }^{60}$ the Salvage Convention 1989 still applies to historic wrecks. ${ }^{61}$

Under the IMO's Strategic Plan (2018-23), the regulation of Maritime Autonomous Surface Ships ("MASS") is a key strategic direction to integrate new and advancing technologies into the regulatory framework. ${ }^{62}$ While the definition of a vessel is broad enough to include MASS under the Salvage Convention $1989{ }^{63}$ the obligation and

MAR. L. J. 65 (2012).

56 Semco Salvage \& Marine PTE. Ltd. v. Lancer Navigation Co., [1997] 1 Lloyd's Rep. 327 (H.L. 1997) (The Nagasaki Spirit). A fair rate is a rate of expense that is comprehensive of indirect or overhead expenses with the additional cost of having resources readily available. Hence, the judgement limited the amount of special compensation that could be paid to mere out-of-pocket expenses without allowance for any profit margin. See A. Gilligan, Nagasaki Spirit: A Recent Decision Affecting Marine Salvage and Environmental Concerns 22 TuL. MAR. L.J. 619 (1997-1998).

57 In 1997, the shipping industry, ISU and the International Group of P\&I Clubs created the "Special Compensation P and I Club" or the SCOPIC clause to avoid the legal problems that the assessment of Special Compensation under Article 14 of the Salvage Convention 1989. It still has the same effect. See L. Jianping, SCOPIC and the SCR, available at http:/www.marine-salvage.com/media-information/conference-papers/scopic-and-the-scr.

58 Id.

59 For example, there was a salvage of SS Gairsoppa which cost USD 20 million for exploration. The salvor got about USD 45.6 million but the United Kingdom only received the remaining USD 11.4 million. See C. Hoefly, National T National Treasure: A survey of the current international law regime for Underwater Cultural Heritage, 4 PENN. ST. J. L. \& INT'L AFF. 817-9 (2016).

602562 U.N.T.S. 3.

61 C. Forrest, Historic Wreck Salvage: An International Perspective, 33 Tul. MAr. L. J. 24-5 (2009). See also O. Varmer \& C. M. Blanco, The Case for Using the Law of Salvage to Preserve Underwater Cultural Heritage: The Integrated Marriage of the Law of Salvage and Historic Preservation, 49 J. MAR. L. \& CoM. 401-24 (2018). Thailand discoved a medieval wreck in the Gulf of Thailand. See P. Howitz, Two ancient shipwrecks in the Gulf of Thailand. A report on archaeological investigations, 65 J. SIAM Soc'Y 1-22 (1977). See also K. Atkinson et al., Joint Thai-Australia Underwater Archaeological Project 1987-88. Part I: Archaeological Survey of Wreck Sites in the Gulf of Thailand, 1987-88, 18 Int’l J. Nautical Archaeology \& Underwater Exploration 299-315 (1989).

62 IMO, Autonomous Shipping, available at http://www.imo.org/en/MediaCentre/HotTopics/Pages/Autonomousshipping.aspx.

63 P. Dean \& H. Clack, Autonomous Shipping and Maritime Law, in New Technologies, Artificial Intelligence AND Shipping Law in the 21st Century 82 (B. Soyer \& A. Tettenborn eds., 2020). 
duty to render assistance between MASS and manned vessels remains unclear. The manned vessel should be entitled to priority where assistance must be rendered, without considering the economic benefit of the potential reward.

The core question is not whether the Salvage Convention 1989 is adequate or inadequate, but rather when is the right time for the conclusion of a new treaty. In the meantime, the conducting of salvage operations and the prevention of environmental damage must continue within the aged legal instruments.

\section{Thailand's Implementation}

Thailand has been an active member of IMO since 1973 and is involved as the current IMO council. According to the dualist system, Thailand must legislate a municipal law incorporating all obligations under the treaty before it may ratify any treaty. Aside from the legal perspective, Thail membership to the Salvage Convention 1989 shall strengthen its role in the international arena especially in the future IMO's council. ${ }^{64}$

On November 28, 2019, Thailand was affected by the deposit of an instrument of accession $^{65}$ and making a reservation as follows: “... [P] ursuant to paragraph (1) (a) of article 30 of the aforesaid Convention, the Kingdom of Thailand reserves the right not to apply the provisions of this Convention when the salvage operation takes place in inland waters and all vessels involved are of inland navigation."

When Thailand ratified the Salvage Convention 1989, it announced to the international community that Thailand already had its domestic salvage law which accorded with this international instrument. In addition, it will provide a benefit for the salvage business and the progressive development of maritime law in Thailand.

The Salvage Convention 1989 entered into force for Thailand one year after the accession, ${ }^{67}$ and its provisions were incorporated into the Marine Salvage Act, B.E.

\footnotetext{
64 The Royal Thai Government, Cabinet Resolution No. 24, Sept. 19, 2020, available at https://www.thaigov.go.th/news/ contents/details/24674. <available only in Thai $>$. Noting that Thailand was re-elected for the eighth consecutive term since 2006. See Ministry of Foreign Affairs of Kingdom of Thailand, Thailand Re-Elected to the International Maritime Organization (IMO) Council for 2020-2021 for the Eighth Consecutive Term, Sept. 29, 2019, available at http://www. mfa.go.th/main/en/news3/6886/111869-Thailand-Re-Elected-to-the-International-Maritime.html.

65 The Salvage Convention 1989, art. 28.

66 IMO, Status of IMO Treaties, Feb. 12, 2020, at 481, available at http://www.imo.org/en/About/Conventions/ StatusOfConventions/Documents/Status\%20-\%202020.pdf.

67 Salvage Convention 1989, art. 29(2).
} 
$2550(2007)^{68}$ (hereinafter the Act), which Thailand had enacted a decade before. The Act, which bases its obligations on the Salvage Convention 1989, is comprised of thirty-four Sections. The purpose of the Act is to establish common practices for salvage and the implementation of the Salvage Convention 1989, which sets the rights, obligations, incentives, and liabilities of each party involved in marine salvage and reducing environmental harms. The following is a summary of the key provisions of the Act:

- Salvage operations under the Act exclude those performed in inland waters without the involvement of seagoing vessels, ${ }^{69}$ warships, non-commercial stateowned vessels, or platforms and drilling units. ${ }^{70}$

- Contracts for salvage operations may be concluded by the master of the vessel on behalf of the owner of the vessel. Concerning contracts regarding the property on board, the master or owner of the vessel should consider such contracts on behalf of the owner. ${ }^{71}$

- In the event of salvage operations producing a useful result, the salvor has the right to earn a reward. ${ }^{72}$ There are nine-criteria to be considered in the specification of the reward. ${ }^{73}$

- The payment of rewards shall be made by all of the vessel owners and other property interests in proportion to their respective salvaged values. The owner of the vessel rendering these rewards shall be entitled to the right of recourse against the interested persons in proportion to the amount of reward that has been paid. ${ }^{74}$ The amount of rewards shall not exceed the salvaged value of the vessel and other property, exclusive of interest and the cost of the legal process. ${ }^{75}$

- In the case of a salvor earning a reward of less than the amount of his expenses, he is entitled to special compensation from the owner of the vessel. If a salvor has prevented damage or mitigated damage to the environment, the special compensation may be increased up to a maximum of $30 \%$ of the expenses incurred by him. The court has the power to further increase such special compensation, but not to exceed twice the amount of the expenses. ${ }^{76}$

- A person saving any victim's life does not receive the right to claim remuneration from persons whose lives are saved but is entitled to a fair share of the payment 
rewarded to the salvor. ${ }^{77}$

- All or some of the payment shall be denied if a salvor was at fault or was guilty of negligence or other misconduct; the salvor may not be entitled to any payment if he has committed fraud or other dishonest conduct, ${ }^{78}$ or engaged in operations against the express and reasonable prohibitions of the owner or master of the vessel or the owner of any other property in danger. ${ }^{79}$

- A salvor is entitled to claim a maritime lien unless satisfactory security for his claim has been duly provided. ${ }^{80}$

- The limitation for salvage service payment is two years, which commences from the day on which the salvage operation was accomplished. ${ }^{81}$ Any claim arising from a salvage operation under the Act is under the jurisdiction of the Central Intellectual Property and International Trade Court. ${ }^{82}$

\section{Conclusion}

The Salvage Convention 1989 establishes the main international legal framework dealing with salvage operations and environmental protection. It is the result of many years of drafting and diplomatic efforts where the treaty was negotiated and concluded. It is undeniable that the Salvage Convention 1989 has encouraged private sector and public authorities to establish and maintain the resources needed to contain ecological damage. This was an important accomplishment. Providing adequate incentives for rapid salvage operation adds to the traditional rewards. Nevertheless, the problems of updating the provisions of the Salvage Convention 1989 need to be addressed and the path ahead is still long and winding.

Received: February 1, 2020

Modified: March 30, 2020

Accepted: May 15, 2020 
